\title{
Development of one-section microchannels cooling system for high-concentration photovoltaic cells
}

\author{
Mohammed Ibrahima, Hala Abdel-Hameed ${ }^{\mathrm{a}}$, Hosny Abou-Ziyan ${ }^{\mathrm{a}, b^{*}}$ \\ ${ }^{a}$ Mech. Power Eng. Dept., Faculty of Engineering, Helwan University, Cairo, Egypt. \\ ${ }^{\mathrm{b}}$ Mech. Power Eng. Dept., College of Technological Studies, PAAET, Kuwait. \\ * Corresponding author: hosnyaz@ hotmail.com; phone: +96599381336; fax: \\ $+96524811753$
}

\begin{abstract}
This paper presents the development of simple, effective and economic microchannel systems for cooling high-concentration multi-junction photovoltaic (HCMJPV) cells. The developed cooling system uses a short cooling fluid path concept with one microchannel section per the fluid path. The work is conducted using a 3D numerical model that is based on the finite volume method. The effects of design parameters on the thermal characteristics of one-section microchannels and output power of the HCMJPV cells are comprehensively investigated. Cooling systems that attained the largest net output power of HCMJPV cells are identified. The developed cooling system achieved superior characteristics compared to the existing state of the art system. The proposed constant-width one-section cooling system achieves comparable standard deviation and lower surface temperature $\left(35.65^{\circ} \mathrm{C}\right)$, pressure drop $(68.41 \%)$ and microchannel thermal resistance $(49.57 \%)$ along with higher generated power $(8.27 \%)$, net output power $(8.44 \%)$ and overall heat transfer coefficient $(175.8 \%)$ than the existed cooling system in literature. The developed cooling system allows the cells to produce an extra $820.5 \mathrm{MWh} / \mathrm{m} 2$ of cells, during their lifetime.
\end{abstract}

\section{Keywords}

High-concentration multi-junction photovoltaic; high power integrated circuits; constant-width microchannel cooling; hybrid jet impingement-microchannel cooling; pumping power; net output power 


\section{Introduction}

The solar energy becomes one of the most important renewable energy sources. It is the third source of power generation in 2018, after the hydraulic and wind power sources, by installed capacity of $486085 \mathrm{MW}$ [1]. Solar energy technologies provide a great role to solve the most pressing problems of conventional energy sources depleting and the increase in energy demand [2]. The solar photovoltaic (PV) cells are considered as the most promising technology of solar energy due to a wide range of applications [3].

The history of PV started by the single-junction cells, but its main weakness is the low conversion efficiency (15-20\%). Also, its conversion efficiency decreases by about $0.08 \%$ for a 1-degree increase in temperature above $25^{\circ} \mathrm{C}$ [4]. Afterward, concentrated photovoltaic (CPV) systems are introduced to enhance the power generation by these low-efficiency solar cells. Nowadays, the most promising PV technology is the multi-junction photovoltaic (MJPV), particularly with high concentration (HCMJPV). Those cells were usually used in the spaceships and become available for terrestrial applications. Triple junction cells consist of three layers of semiconductors that can absorb a wide range of incident rays (many wavelengths). Thus, the efficiency of commercial triple-junction PV is $38-43 \%$ at a cell temperature of $25^{\circ} \mathrm{C}$ [1]. The conversion efficiency of HCMJPV is decreased by $0.05-0.15 \% /{ }^{\circ} \mathrm{C}$ increase above $25^{\circ} \mathrm{C}[1,5]$.

Therefore, cooling the surface of the PV cells becomes a very important issue to sustain reasonable efficiency of the cells. HCMJPV technology requires an efficient cooling system [6]. Active methods of cooling HCPV such as forced air and liquids, liquid film or spray, microchannels, jet impingement, and hybrid jet impingement-microchannels can overcome the existing challenges of passive systems [5]. Nižetić et al. [7, 8] reviewed and assessed the economic viability of passive and active cooling techniques of PVs.

In the last few years, the cooling systems of high densely packed PV and high power integrated circuits have incredible advancements and improvements. The main aims are providing low thermal resistance of heat transfer to maintain the temperature of cells at proper operating temperature and improving the temperature uniformity to maintain their reliability and efficiency of cells [9-10]. On the other hand, the compromise between the consumed pumping power of the cooling system and power increased due to cooling must be considered. The most critical cooling is for densely packed cells, which must be cooled actively and the thermal resistance has to be less than $10^{-4} \mathrm{~m}^{2} \mathrm{~K} / \mathrm{W}$ [11]. "The densely packed cells are those where each cell is surrounded by other cells on each side, excluding the cells placed on the edges of the assembly $[11,15]$ ". Such a very low level of thermal resistance can be achieved only by impinging jets and microchannels.

The microchannel system is considered as one of the most powerful technologies in liquid cooling. Microchannels can be integrated as liquid cold plates (heat sink) or itched in the surface of HCMJPV and integrated circuits. Microchannels are defined 
by their channel dimensions, which are typically $10-200 \mu \mathrm{m}$ or up to $1-3 \mathrm{~mm}$ in some cases. Microchannels provide high heat transfer rates due to high heat transfer coefficients and high heat transfer area per unit volume. However, pressure drops are also enlarged for microchannels [12].

Tuckerman et al. [13] were the first who used microchannels for cooling integrated circuits. Their results indicated that heat transfer is decreased gradually along the path of water, which leads to very poor temperature uniformity. Lee et al. [14] replaced the continuous fins of microchannels by sectional oblique fins cut at $27^{\circ}$ to improve the temperature uniformity. The authors reported an enhanced heat transfer by $30 \%$ with a slight increase in pressure drop compared to the conventional microchannel cooling system. Micheli et al. [15] showed that the maximum temperature of the cooled surface was $78.8^{\circ} \mathrm{C}$ for flat plate and $70.4^{\circ} \mathrm{C}$ for the finned plate. Reddy et al. [16] investigated the effects of microchannels width (0.2$0.4 \mathrm{~mm})$, aspect ratio $(0.2-0.5 \mathrm{~mm})$ and Reynolds number $(500-1500)$ on the thermal and electrical performance of the cooling system. They concluded that microchannels of $0.5 \mathrm{~mm}$ width, $4 \mathrm{~mm}$ depth, and $12 \mathrm{~mm}$ length provided a minimum pressure drop. However, the temperature of the cooled surface was high even at high flow rates.

Some studies investigated the performance of microchannels with different crosssectional shapes such as hexagonal, circular, and rhombus cross-sectional microchannels [17] or circle, square, trapezium, two concave surfaces, and two convex surfaces [18]. However, these designs are very complicated and very expensive to manufacture. T-shaped microchannels cooling systems with different configurations were investigated [19]. Also, T-shaped microchannels itched on the surface of the PV base with five serial steps were considered [20]. The effects of the width of microchannels, the number of manifolds, and the water flow rate on the performance of the manifold (multi-layered) microchannel cooling system were investigated [21-22]. The results showed that the best model had channels of $0.025 \times 0.3 \mathrm{~mm}$. However, this design is complicated to manufacture and it needs a high flow rate which causes a very high-pressure drop. Nanofluids were used to enhance the heat transfer coefficient without increasing the flow rate in a trial to decrease the high-pressure drop in the manifold microchannels [23-24]. Other models were designed to enhance the convection coefficient by increasing the turbulence in the flow path such as wavy [25-26], U [27], and microscale ribs and grooves [28] microchannels. All those models enhance the heat transfer, but increase the consumed pumping power and become more difficult to manufacture especially for microscale applications.

On the other hand, as the jet impingement can achieve high local heat transfer coefficient it was used for cooling high-performance ICs and densely packed PVs. The effects of the jets number and the nozzle pitch on industrial CPVs are investigated where the system offers low pressure drop, but gives a high temperature of the cooled surface with bad temperature uniformity, even under low heat flux [10]. The effects of jet-to-jet spacing, nozzle-to-plate distance, and flow 
rate on the performance of a cooling system of a flat plate with three air jets impingement were investigated [29]. The results indicated that the optimum jet-tojet spacing was four times the jet diameter as it maximizes Nusselt number and minimizes the negative effect of interaction between jets.

Hybrid jet impingement-microchannel is the most appropriate cooling system to achieve low thermal resistance [11]. Naphon et al. [30] showed that for the hybrid fixed nozzle microchannel system (single pass), the heat transfer coefficient increases but the pressure drop increases by decreasing the jet diameter. Dede [31] optimized a new model of hybrid multi pass branching microchannel-jet impingement cooling system. This model provided a low pressure drop but with bad cooling performance. Lamini et al. [32] investigated models of fixed and moving nozzles where the results provided that the mean temperature was dropped by $5^{\circ} \mathrm{C}$ by using the moving nozzle. This model had excellent thermal performance but provided bad temperature uniformity. Han et al. [33] proposed a new design to eliminate the problem of the negative cross-flow effect between the adjacent nozzles. The results provided that the heat transfer coefficient was enhanced due to the impingement of jets array over the small cooled surface. Ming et al. [34] suggested combining dimples with hybrid microchannels-jet impingement. Their results indicated that by increasing the radius of dimples, the heat transfer enhanced and the temperature uniformity improved, but the maximum temperature increased.

Barrau et al. [35] proposed a milliscale model of the hybrid cooling system with three stepwise channels per fluid path; their widths were $3.5,1.5$, and $0.5 \mathrm{~mm}$. In this model, the heat transfer coefficient increased gradually through the steps of microchannels due to the enhancement of velocity to compensate for the increase in temperature of the water. Then, Barrau et al. [36] compared their hybrid cooling system for densely packed PV with other microchannels cooling systems reported in [37]. The results showed that the hybrid cooling system provided lower standard deviation and minimum thermal resistance, but had lower net output power for concentration ratio 1905. Also, the temperature uniformity was improved by increasing the flow rate and decreasing the heat flux [38]. This hybrid system operated under high flow rates to enhance the rate of heat transfer and achieved a minimum thermal resistance of $2.18 \times 10^{-5} \mathrm{~m}^{2} \mathrm{~K} / \mathrm{W}$. Moreover, for HCMJPV and high power IC chips, five stepwise microchannel cooling system with variable widths $1.53-0.14 \mathrm{~mm}$ (Fig. 1) was experimentally investigated by Riera et al. [9, 39]. This system has one jet inlet and two outlets and includes thermal interface material (TIM) between the copper layer and the heat sink device (silicon microchannel). This TIM had a low thermal conductivity of $0.82 \mathrm{~W} / \mathrm{mK}$ to improve the smoothness of temperature uniformity. The model achieved a high heat transfer rate and a more uniform temperature distribution, under a lower water flow rate and higher inlet water temperature. Also, the system achieved a lower microchannel thermal resistance of $2.35 \times 10^{-5} \mathrm{~m}^{2} \mathrm{~K} / \mathrm{W}$. The TIM affects the temperature distribution by its smoothing effect and the temperature uniformity improved by decreasing the smoothing resistance [40]. Finally, Vilarrubi et al. [41] replaced the ordinary stepwise microchannels by variable density micro pin-fins that provided the same 
trend of total thermal resistance as ordinary microchannels. They showed that the pressure drop generated at jet impingement/pin fins is higher than that generated at the jet impingement/microchannel cooling system. This design improves the temperature uniformity over the cooled surface due to good mixing of the fluid at high flow rates.

The above literature review indicated that the state of the art cooling system for HCMJPV cells is based on five stepwise microchannel sections with widths of $0.14-1.54 \mathrm{~mm}$ [9]. In this system, the cooling fluid loses considerable pressure drop as it passes through the five microscale sections. Thus, considerable pumping power is needed to operate the system. Although the system is adequate, it is complicated and expensive to manufacture, operate and maintain. On the other hand, the effects of design parameters on the thermal and electrical characteristics of the HCMJPV cells were not studied for a hybrid jet impingement microchannel cooling system yet. In addition, most of the other cooling systems were suffering a high-pressure drop, high surface temperature or bad temperature uniformity.

Therefore, the purpose of the present work is to create a simpler, more efficient and less expensive cooling system for HCMJPV cells. This system is based on the idea of using a short cooling fluid path with one-section microchannels instead of the five-stepwise sections. Thus, the system becomes simple and consumes less pumping power to operate. A comprehensive investigation of the effects of the system design parameters on the thermal characteristics of the cooling system and the output power of the HCMJPV cells is conducted. The design parameters include inlet jet impingement width, outlet slot width, microchannels width, length, and depth. Also, two more conductive thermal interface materials are exercised with the new system as this will make the system more efficient. In addition, the developed designs are compared with the state of the art cooling system.

\section{Numerical Modeling and Simulation}

This section describes the modeling and simulation of water flow and heat transfer in the cooling system of HCMJPV cells. Three-dimensional models that are based on CFD code (FLUENT 18.2) integrated with three user-defined functions (UDFs) were used to simulate the cooling system. The program is based on a finite control volume approach that uses an unstructured mesh to obtain a high resolution of nodes. The equations for conservation of mass (equation 1), conservation of momentum (equation 2) and conservation of energy (equation 3) were solved in each cell.

$$
\begin{gathered}
\frac{\partial \rho}{\partial t}+\frac{\partial}{\partial x_{i}}\left(\rho u_{i}\right)=0 \\
\frac{\partial}{\partial t}\left(\rho u_{i}\right)+\frac{\partial}{\partial x_{j}}\left(\rho u_{i} u_{j}\right)=-\frac{\partial p}{\partial x_{i}}+\frac{\partial}{\partial x_{j}}\left[\mu\left(\frac{\partial u_{i}}{\partial x_{j}}+\frac{\partial u_{j}}{\partial x_{i}}\right)\right]+\rho g_{i}
\end{gathered}
$$




$$
\frac{\partial}{\partial t}(\rho T)+\frac{\partial}{\partial x_{i}}\left(\rho u_{i} T\right)=\frac{\partial}{\partial x_{i}}\left[\frac{k}{c_{p}} \frac{\partial T}{\partial x_{i}}\right]+S_{T}
$$

where $\rho$ is the density of the fluid, $\mathrm{t}$ is time, $u_{i}$ is the velocity vector components ( $\mathrm{u}$, $\mathrm{v}$, and $\mathrm{w}), x_{i}$ is the Cartesian coordinate axis $(\mathrm{x}, \mathrm{y}$, and $\mathrm{z}), \mathrm{p}$ is the pressure, $\mu$ is the dynamic viscosity, and $\rho g_{i}$ is the body force in the $\mathrm{x}, \mathrm{y}$, and $\mathrm{z}$ directions, $\mathrm{T}$ is the temperature, $\mathrm{k}$ is the thermal conductivity of the material, $c_{p}$ is the specific heat, and $S_{T}$ is the source term.

Turbulence was considered using the Reynolds Averaged Navier-Stokes (RANS) equations by time-averaging equations 1-3 and a two-equation turbulence model was chosen to account for the additional terms generated for this method. The appropriate turbulence model for the present cooling system is RANS Realizable k$\varepsilon$ model because the studied cooling system has a low level of turbulence without strong vorticity. Also, the required initial layer of water mesh inflation is not very fine and allowed the value of $Y^{+}>30$. This reduces the required number of cells and required computational time and cost. In addition, this model has been widely validated for a wide range of flows including jets and mixing flows, channel and boundary layer flows, and separated flows.

\subsection{Computational domains:}

The cooling system needs to be able to cool a PV module that is consisting of 5 HCMJPV cells where each cell is $1 \times 1 \mathrm{~cm}$. Thus, the cooling system size is $5 \mathrm{~cm}$ long by $1 \mathrm{~cm}$ wide and $2.2 \mathrm{~mm}$ high. Fig. 2 shows the cooling system that was proposed and examined, in this work, for HCMJPV cells. The system contains four similar microchannel stages (i.e. four cooling water paths) with two water inlets and three outlets as shown in Fig. 2.

Figure 2 shows that the cooling system is symmetric in the $\mathrm{XZ}$ plane and $\mathrm{YZ}$ plane. Therefore, a quarter of the cooling system is representative of the full cooling system. Thus, the simulation is conducted on a quarter of the cooling system. It can be seen that the water jets are introduced through the inlet slot, in the middle at $\mathrm{x}=12.5 \mathrm{~mm}$, where each jet cools half the HCMJPV surface and discharged through two outlet slots at the ends of the cooled sections, at $x=0$ and $x=25 \mathrm{~mm}$.

\subsection{Model solver description:}

The cooling system is constructed of four layers, namely the copper base, thermal interface material (TIM), silicon wafer microchannels as a heat sink (cooling device) and water as a cooling liquid. Tetrahedral cells are used for water and silicon microchannels domains and hexahedral cells for the thermal interface material and copper layers. In addition, some modifications are performed to improve the quality of the grid which is evaluated by the aspect ratio, skewness, and orthogonal quality. Specifically, the edge sizing is used for edges of microchannels and water domains and creates inflation layers on the walls of the liquid domain. 
Navier-Stokes equations are solved in the fluid domain with turbulent flow under the range of investigated parameters of inlet water temperature, velocity and heat flux. The steady, pressure-based coupled algorithm method was used to solve the problem as it obtains more robust and efficient single-phase implementation for steady-state flows. Least Squares Cell Based is used for gradient, second-order upwind discretization is used for energy and momentum and second order is used for pressure to control the spatial discretization of the convection terms in the equations. The pseudo transient helps to stabilize the case and at the same time gives faster convergence.

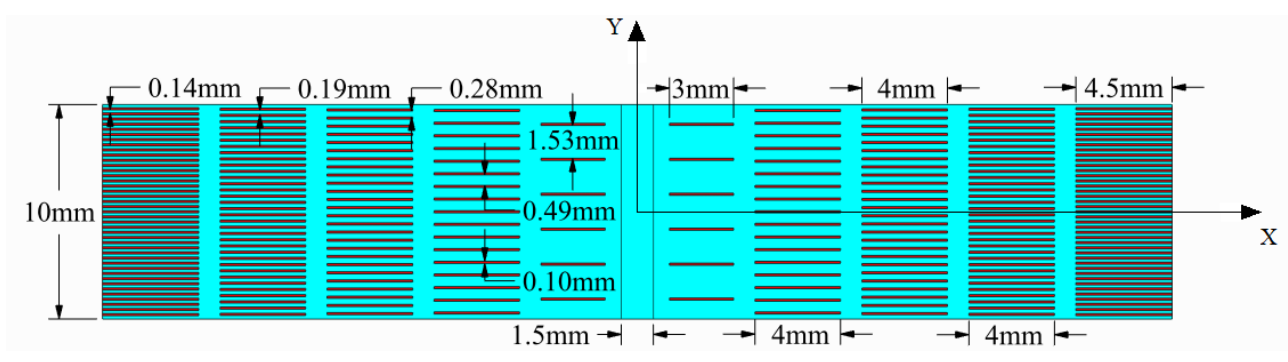

Figure 1. Schematic diagram of the five stepwise microchannel cooling system [9]
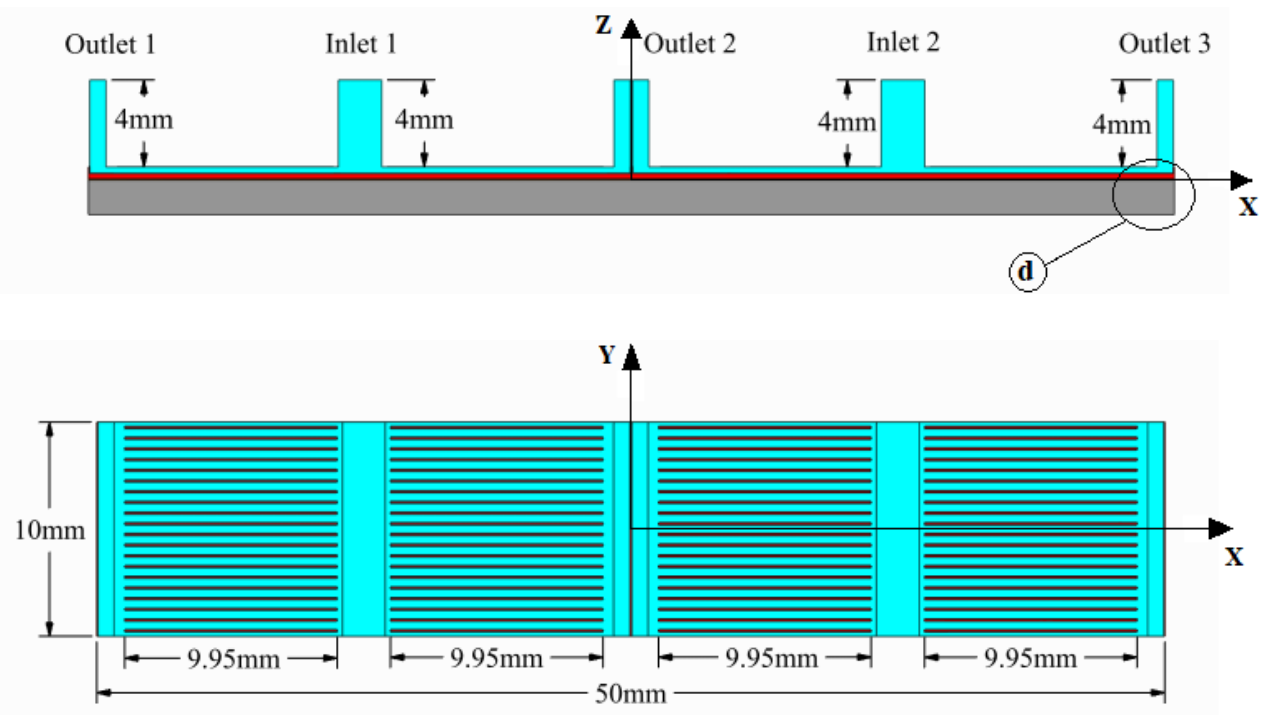

Figure 2. Schematic diagram of the one-section cooling system for HCMJPV

The direct normal solar irradiance DNI is incident on the double stage Fresnel lens. Then, the surface of HCMJPV receives this concentrated solar energy; part of it is converted to generate power, and the rest is transferred to the body of HCMJPV as heat. This heat is conducted through the copper base, thermal interface materials, and silicon anisotropic microchannels layers, and then transferred by convection to the cooling liquid.

The correct simulation of the cooling system depends on the appropriate specifications of the boundary conditions. Each simulation was assumed to converge when the residuals for the energy equation were less than $10^{-8}$ and those for the equations of continuity and momentum were less than $10^{-5}$. Program inputs 
are water flow rate, inlet water temperature, and heat flux, in addition to the geometry of the cooling system. On the other hand, the outputs from the program are HCMJPV surface temperature, a standard deviation of temperature, and inlet and outlet pressure.

\subsection{Model validation}

The described numerical model is validated against experimental data reported in [9] where the HCMJPV cooling system is made up of two stages (fluid paths) each stage comprised five stepwise microchannel sections per the fluid path as described in section 1 (Fig. 1). Minor changes were implemented in the numerical model to accommodate the various conditions of the experiment in [9] including the flow type and the boundary conditions. The material and fluid properties were taken as reported in [9] or through private communication with the authors. Only, the properties of the anisotropic silicon wafer used in their work were not available; thus, these properties are not certain in the model.

\subsubsection{Mesh independent study:}

Accurate numerical predictions require a mesh that is sufficiently refined to obtain results that are independent of the mesh used. The mesh independent study was conducted for three sizes; namely 10.5 MCells (2.77M nodes), 11.9 MCells (3.55M nodes) and 18.3 MCells (5.01M nodes). Fig. 3a shows the temperature distribution in the middle width $(\mathrm{y}=5 \mathrm{~mm})$ of the copper base at $\mathrm{z}=-1.25 \mathrm{~mm}$ where the thermocouples are located in the experimental work [9]. Similar results are shown for the three mesh sizes for $x>10 \mathrm{~mm}$ (the last three microchannel sections). The difference between the results is noted for the fluid entrance where the inlet jet impinges the surface and first two-stepwise microchannel sections. The large size grid (10.5 MCells) fails to predict accurate results under the conditions in this area. However, the difference between results of 11.9 and 18.3 MCells is minor while the difference in computation time is significant. Therefore the mesh size, of 3.55 million nodes and 11.9 million cells, provide accurate results and reasonable computation time and was used throughout the validation and system modeling.

\subsubsection{Validation results}

Figure $3 \mathrm{~b}$ shows the experimental and numerical distribution of two experimental tests [9] at $\mathrm{z}=-1.25 \mathrm{~mm}$. It is clear that the average error along the curve is $\pm 3.643 \%$ $\left(2.94^{\circ} \mathrm{C}\right)$, for test 1 and $\pm 4.04 \%\left(3.19^{\circ} \mathrm{C}\right)$, for test 2 . Considering the uncertainty in the experimental results which is about $\pm 2.11 \%\left(1.6^{\circ} \mathrm{C}\right)$, it reveals that the difference between the experimental and predicted results is between $1.6 \%$ for test 1 and $2 \%$ for test 2 . The small difference between experimental and predicted results may be attributed to the uncertainty in the thermophysical properties of materials that weren't available and the uncertainty in the experimental results. In conclusion, the numerical model predicts the results accurate enough within an average range of 0 to $1.93 \%$. 


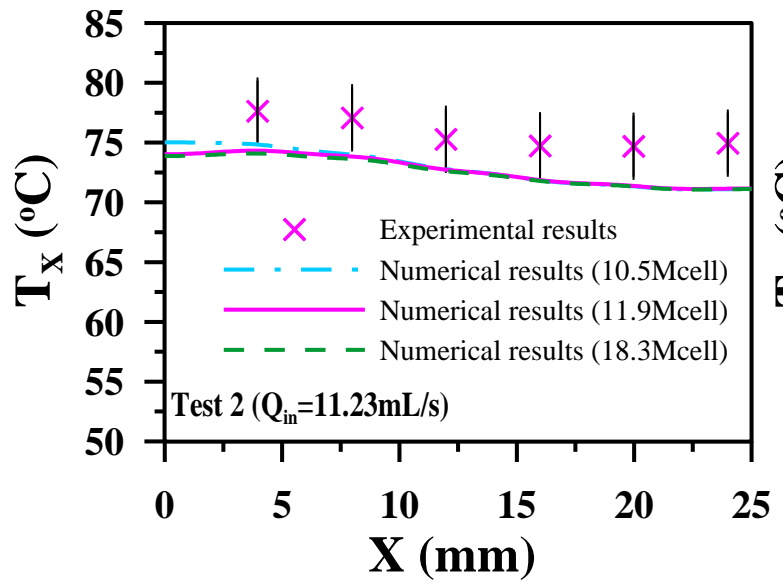

(a)

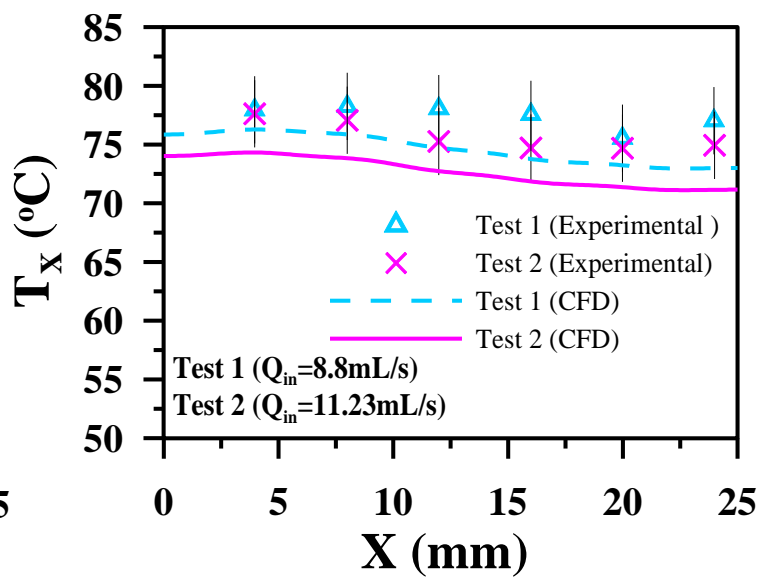

(b)

Figure 3. The validation of the numerical model.

\section{Analysis of Output Power and Cooling of HCMJPV}

The implementation of an idea or a new concept to the cooling process of HCMJPV cells targets to decrease the thermal resistance while maintaining the temperature uniformity of the cooled HCMJPV surface. The accomplishment of this target depends on the successful design that optimizes the use of suitable materials and flow conditions. The total thermal resistance $\left(\mathrm{R}_{\mathrm{t}}\right)$, microchannel global thermal resistance $\left(R_{m}\right)$ and the overall heat transfer coefficient $(U)$ can be evaluated using equations 4-6.

$$
\begin{gathered}
\mathrm{R}_{\mathrm{t}}=\frac{\mathrm{T}_{\mathrm{a}}-\mathrm{T}_{\mathrm{in}}}{\mathrm{q}^{\prime \prime}} \\
\mathrm{R}_{\mathrm{m}}=\mathrm{R}_{\mathrm{t}}-\frac{\mathrm{L}_{\mathrm{cu}}}{\mathrm{k}_{\mathrm{cu}}}-\frac{\mathrm{L}_{\mathrm{TIM}}}{\mathrm{k}_{\mathrm{TIM}}} \\
\mathrm{U}=\frac{1}{\mathrm{R}_{\mathrm{t}}}
\end{gathered}
$$

Where $T_{a}$ is the average surface temperature of HCPV base, $T_{i n}$ is the inlet water temperature, $\mathrm{q}^{\prime \prime}$ is the heat flux, $\mathrm{L}_{\mathrm{cu}}$ and $\mathrm{k}_{\mathrm{cu}}$ are thickness and thermal conductivity of copper layer, and $\mathrm{L}_{\mathrm{TIM}}$ and $\mathrm{k}_{\mathrm{TIM}}$ are thickness and thermal conductivity of thermal interface layer.

The inlet water velocity $\left(\mathrm{V}_{\text {in }}\right)$ is calculated to define the inlet boundary condition of numerical simulation using equation 7 in which $Q$ is the volume flow rate of water, and $A$ in is the area of the inlet slot jet.

$$
\mathrm{V}_{\text {in }}=\frac{\mathrm{Q}}{\mathrm{A}_{\mathrm{in}}}
$$

On the other hand, the generated power $\left(\mathrm{P}_{\mathrm{g}}\right)$ and consumed pumping power $\left(\mathrm{P}_{\mathrm{p}}\right)$ are calculated using equations 8 and 9 , respectively. Then, the most important performance factor of the HCMJPV, which is the net output power $\left(\mathrm{P}_{\text {net }}\right)$ can be 
evaluated using equation 10 . Thus, the characteristics of the cooling system control the net output power because the HCMJPV surface temperature influences the generated power and the pressure drop $(\Delta \mathrm{p})$ across the cooling system controls the pumping power.

$$
\begin{gathered}
\mathrm{P}_{\text {net }}=\mathrm{P}_{\mathrm{g}}-\mathrm{P}_{\mathrm{P}} \\
\mathrm{P}_{\mathrm{P}}=\Delta \mathrm{p} \times \mathrm{Q} \\
\mathrm{P}_{\mathrm{g}}=\mathrm{q}_{\mathrm{g}} \times \mathrm{A}_{\mathrm{s}}
\end{gathered}
$$

$\mathrm{q}_{\mathrm{e}}$ is the generated electrical power per unit area of HCMJPV cell and $\mathrm{A}_{\mathrm{s}}$ is the surface area of the cell. It is calculated using equation 11 and the conversion coefficient $\eta_{c}\left(T_{a}\right)$ of HCMJPV is estimated using equation 12 .

$$
\begin{gathered}
\mathrm{q}_{\mathrm{e}}=(\mathrm{CR} \times \mathrm{DNI}) \times \mathrm{\eta}_{\mathrm{c}}\left(\mathrm{T}_{\mathrm{a}}\right) \\
\mathrm{\eta}_{\mathrm{c}}\left(\mathrm{T}_{\mathrm{a}}\right)=\mathrm{\eta}_{\mathrm{c}}(25)-\alpha(25)
\end{gathered}
$$

Where CR is the concentration ratio of solar concentrator facility, DNI is the direct normal solar irradiance, $\eta_{c}\left(T_{a}\right)$ is temperature dependence convergent coefficient of HCMJPV cell, $\eta_{\mathrm{c}}(25)$ is the convergent coefficient at the surface temperature of $25^{\circ} \mathrm{C}$ and equals $39.2 \%$ [38]. The parameter $\alpha$ is the relative temperature coefficient of HCMJPV cell $\left(\% /{ }^{\circ} \mathrm{C}\right)$. This factor indicates the percentage decreasing into the convergent coefficient by increasing the surface temperature by $1{ }^{\circ} \mathrm{C}$ and equals 0.0531 [38] for the considered solar cell. It is to be indicated that $\mathrm{T}_{\mathrm{a}}$ is dependent strongly on the effectiveness of the cooling system.

\section{Results and Discussion}

In this section, the comparison between the considered cooling systems are based on surface temperature $\left(\mathrm{T}_{\mathrm{a}}\right.$ or $\left.\mathrm{T}_{\mathrm{mw}}\right)$, temperature uniformity along the HCMJPV base which is measured by the standard deviation $\left(\sigma_{\mathrm{a}}\right.$ or $\left.\sigma_{\mathrm{mw}}\right)$ of temperature, total $\left(\mathrm{R}_{\mathrm{t}}\right)$ and microchannels $\left(\mathrm{R}_{\mathrm{m}}\right)$ thermal resistance and net output power $\left(\mathrm{P}_{\text {net }}\right)$. It has to be stated that the cooling system is $5 \mathrm{~cm} \times 1 \mathrm{~cm}$ and is responsible for cooling a module of five HCMJPV cells each is $1 \mathrm{~cm} \times 1 \mathrm{~cm}$. Thus, a square meter contains 2000 modules or 10000 HCMJPV cells. Therefore, the cooling system that produces a higher net output power of the module by $0.01 \mathrm{~W}$ produces an extra $20 \mathrm{~W}$ per square meter of cells that is about $0.16 \mathrm{kWh} /$ day or $58.4 \mathrm{kWh}$ a year and $1.46 \mathrm{MWh}$ during the cell's lifetime (25 years). Similarly, $1 \mathrm{~W}$ difference in the net power produced by the considered module generates an extra $146 \mathrm{MWh}$ per square meter of cells, during their lifetime. However, the effects of design parameters on the output power and the cooling effectiveness of the HCMJPV cells for constantwidth one-section microchannels cooling system is discussed in the following subsections. It has to be stated here that the study is conducted under the following boundary conditions: inlet water temperature of $21.7^{\circ} \mathrm{C}$, heat flux of $50 \mathrm{~W} / \mathrm{cm}^{2}$, and inlet water velocity of $0.44 \mathrm{~m} / \mathrm{s}$. Those parameters are taken similar to test 1 of Reira et al. [9] to facilitate a comparison between present work and their existed design. 
In order to obtain the best design of this constant-width one-section cooling system, five design parameters are investigated. These include inlet jet width $(1,1.5,2,2.5$ and $3 \mathrm{~mm})$, outlet slot width $(0.5,0.75$ and $1 \mathrm{~mm})$, microchannel width and depth $(0.2,0.3,0.4$ and $0.5 \mathrm{~mm})$ and finally the thermal interface material, TIM $(\mathrm{k}=0.82,3$ and $4 \mathrm{~W} / \mathrm{mK}$ ). Table 1 (sections a-e) lists the results of the stated effects of design parameters, respectively. Also, Figs. 4a-4e show the temperature distributions along the cell surface of the cooling system shown in Fig. 2, for the different stated design parameters.

\subsection{Effect of inlet jet width}

The effect of inlet slots is investigated for a width of $1.0,1.5,2.0,2.5$ or $3.0 \mathrm{~mm}$ while the outlet slot width remains unchanged at $0.75 \mathrm{~mm}$. The effect of inlet slot width on the thermal characteristics of the cooling system and output power of the HCMJPV is presented in Fig. 4a and Table 1 (section a).

Table 1. Effect of design parameters on the thermal and electrical characteristics of constant-width one-section microchannels cooling system

\begin{tabular}{|c|c|c|c|c|c|c|c|c|c|c|c|c|}
\hline & & $\begin{array}{l}\mathrm{T}_{\mathrm{a}} \\
{ }^{\circ} \mathrm{C}\end{array}$ & $\begin{array}{l}\sigma_{\mathrm{a}} \\
{ }^{\circ} \mathrm{C}\end{array}$ & $\begin{array}{c}\mathrm{T}_{\mathrm{mw}} \\
{ }^{\circ} \mathrm{C}\end{array}$ & $\begin{array}{c}\sigma_{\mathrm{mw}} \\
{ }^{\circ} \mathrm{C}\end{array}$ & $\begin{array}{l}\mathrm{R}_{\mathrm{t}} \times 10^{-5} \\
\mathrm{~m}^{2} \mathrm{~K} / \mathrm{W}\end{array}$ & $\begin{array}{l}\mathrm{R}_{\mathrm{m}} \times 10^{-5} \\
\mathrm{~m}^{2} \mathrm{~K} / \mathrm{W} \\
\end{array}$ & $\begin{array}{c}\mathrm{U} \\
\mathrm{kW} / \mathrm{m}^{2} \mathrm{~K}\end{array}$ & $\begin{array}{c}\Delta \mathrm{p} \\
\mathrm{kPa}\end{array}$ & $\begin{array}{l}\mathrm{P}_{\mathrm{p}} \\
\mathrm{W}\end{array}$ & $\begin{array}{l}P_{g} \\
W\end{array}$ & $\begin{array}{l}P_{\text {net }} \\
W\end{array}$ \\
\hline \multirow{5}{*}{$\begin{array}{l}\text { a. } \\
\text { Inlet jet width } \\
(\mathrm{mm})\end{array}$} & & & & 5.68 & & & & & & & 3.47 & 84 \\
\hline & & & & & & 8.13 & & & & & & 68.4 \\
\hline & & & 3344 & 510 & & 8.85 & & & 15.26 & & & 68.4 \\
\hline & 2.5 & 5.07 & 0.1966 & 6.31 & 0.1972 & 8.87 & 2.36 & 11.27 & 15.34 & & 3.66 & 68.3 \\
\hline & & & & .62 & 950 & 93 & & & 5.47 & & & 8.3 \\
\hline \multirow{3}{*}{$\begin{array}{c}\text { b. } \\
\text { Outlet slot } \\
\text { width }(\mathrm{mm})\end{array}$} & & & & 606 & & & & & 1560 & & 68.69 & \\
\hline & & & & & & .85 & & & 5.26 & & .68 & 68.4 \\
\hline & & .94 & 343 & 0.11 & 0.3344 & 8.86 & 2.35 & 11.30 & 15.37 & 0.2704 & 68.68 & 68.4 \\
\hline \multirow{4}{*}{$\begin{array}{c}\text { c. } \\
\text { Width of } \\
\text { microchannels } \\
(\mathrm{mm})\end{array}$} & & & & & & & & & .26 & & & s. \\
\hline & & & & & & 9.30 & & & 9.915 & & & \\
\hline & & & & & & & & & 7.963 & & & \\
\hline & & .78 & 0.4769 & 71.03 & 0.4772 & 9.82 & 3.340 & & 7.091 & & 67.93 & 67.8 \\
\hline \multirow{4}{*}{$\begin{array}{c}\mathrm{d} . \\
\text { Channel depth } \\
(\mathrm{mm})\end{array}$} & & & & & & & & & & & & 00. \\
\hline & & & & 66.10 & & 8.85 & & & 15.26 & & 3.68 & 68. \\
\hline & 0.40 & 66.58 & 0.3843 & 66.73 & 0.3856 & 8.98 & 2.47 & 11.14 & 8.887 & & 8.58 & .4 \\
\hline & & .87 & 0.4168 & 7.08 & & 9.03 & 2.5 & 7 & 6.131 & & 68.53 & .4 \\
\hline \multirow{3}{*}{$\begin{array}{c}\mathrm{e} . \\
\underset{\mathrm{T}}{\mathrm{TIM}} \\
(\mathrm{W} / \mathrm{mK})\end{array}$} & & .90 & 0.3344 & 6.10 & & 8.85 & & & & & 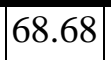 & 68.4 \\
\hline & & 43.75 & 0.5963 & 43.94 & 0.5996 & 4.41 & 2.33 & 22.67 & 15.26 & & 72.11 & 71.8 \\
\hline & & 41.70 & 0.6462 & 41.85 & 0.6487 & 4.00 & 2.34 & 24.99 & 15.26 & 0.2685 & 72.43 & 72.1 \\
\hline \multirow{2}{*}{$\begin{array}{c}\mathrm{f} . \\
\text { Maximum } \mathrm{P}_{\text {net }}\end{array}$} & & 66.12 & 0.4885 & 66.23 & 0.4885 & 8.88 & 2.37 & & 9.174 & 0.1615 & 68.65 & 68.4 \\
\hline & & 41.82 & 0.9046 & 42.00 & 0.9079 & 4.02 & 2.36 & 24.85 & 9.151 & 0.1610 & 72.42 & 12.2 \\
\hline
\end{tabular}



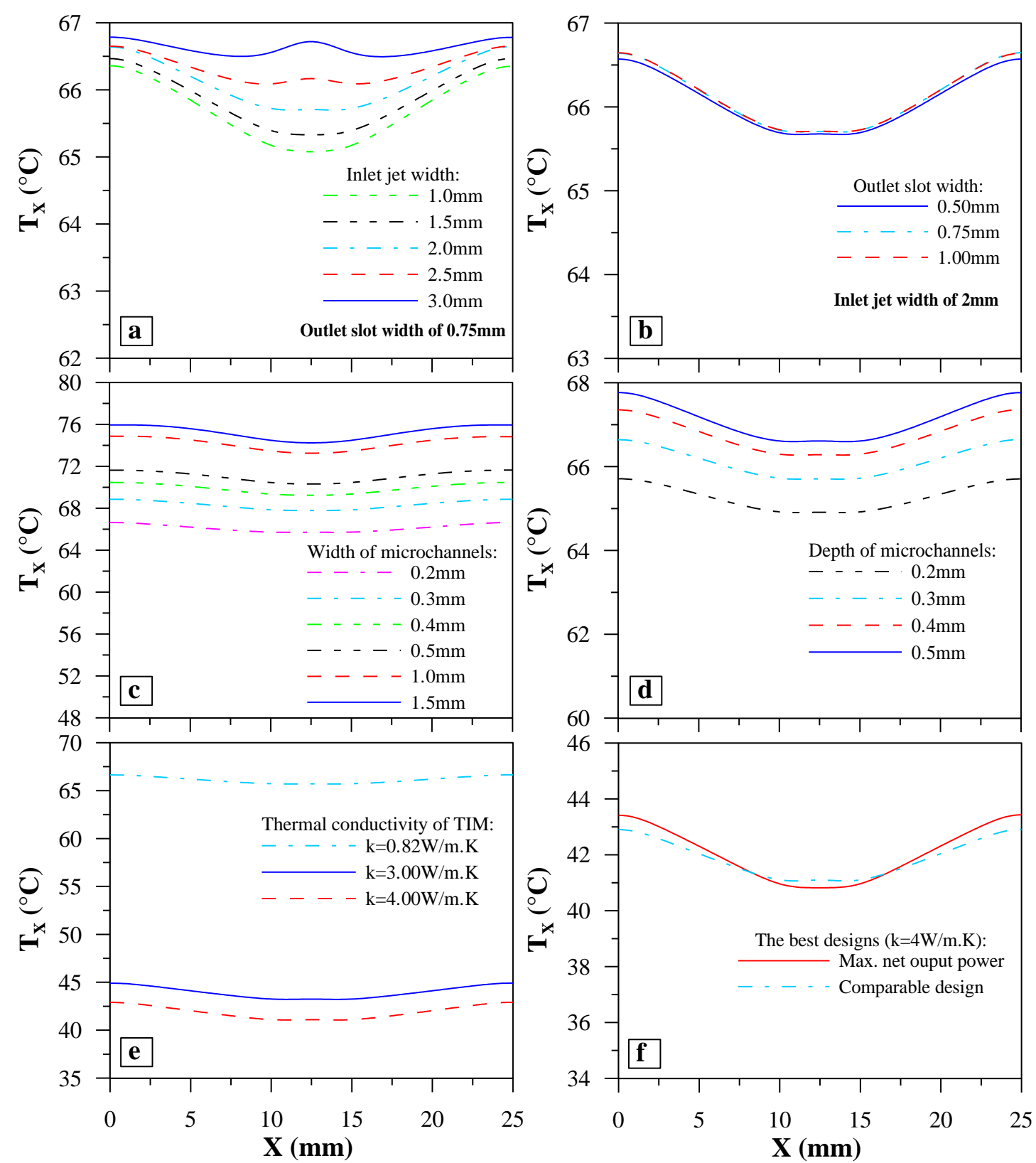

Figure 4. Effect of design parameters on the temperature distribution of the cooling system, a. inlet jet width; b. outlet slot width; c. width of microchannels; d. depth of microchannels; e. thermal conductivity of TIM and f. best designs.

Figure $4 \mathrm{a}$ shows that jets of width lower than $2.5 \mathrm{~mm}$ have the lowest temperature at $\mathrm{x}=12.5 \mathrm{~mm}$ as the inlet jet impinges the cell surface whereas jets with a width of 2.5 and $3 \mathrm{~mm}$ have different temperature distribution along the length of the cell base. This is due to the reduction of the water velocity out of the jet with the increase in the jet width. It is clear that as the inlet slot width is increased the temperature distribution improves while its magnitude increases.

Table 1a indicated that the lowest cell surface temperature and the largest net output power are produced with an inlet jet width of $1.0 \mathrm{~mm}$. But, the temperature uniformity improves as the standard deviation of surface temperature decreases to 
reach its minimum value at a width of $3 \mathrm{~mm}$. Thus, a compromise between the cell temperature and its associated standard deviation suggests that the inlet slot of $2 \mathrm{~mm}$ provides reasonable values for cell temperature $\left(65.9^{\circ} \mathrm{C}\right)$ and its standard deviation $\left(0.334^{\circ} \mathrm{C}\right)$ as listed in Table 1a. However, minute changes of overall heat transfer coefficients, total and microchannel thermal resistances occur within the investigated range of inlet slot width. It is noted that the difference between the average surface temperature and the average middle width temperature is small. Also, the difference between their corresponding standard deviation is small.

\subsection{Effect of outlet slot width}

Outlet water slots are investigated for a width of $0.5,0.75$ or $1 \mathrm{~mm}$ while the inlet width is kept unchanged at $2 \mathrm{~mm}$. Fig. $4 \mathrm{~b}$ and Table $1 \mathrm{~b}$ demonstrated that the effect of outlet slot width is insignificant compared to that of inlet jet width. Table $1 \mathrm{~b}$ indicated that a water outlet width of $0.75 \mathrm{~mm}$ provides slightly lower pressure drop and pumping power compared to the other considered water outlet width. Net output power is not sensitive to the investigated values of water outlets' width.

\subsection{Effect of microchannel width}

The microchannel width is changed from 0.2 to $0.5 \mathrm{~mm}$ with a step of $0.1 \mathrm{~mm}$. Fig. $4 \mathrm{c}$ shows the temperature distribution along the cell surface of the cooling system, for the different cases of microchannel width. It is clear that the temperature and its variation along the surface decrease as the microchannel width is decreased. Also, the lowest HCMJPV surface temperature occurs in the middle where the inlet jet impinges the surface $(x=12.5)$. Then, the temperature of the cell base is increased gradually towards the water outlets.

Table $1 \mathrm{c}$ indicates that reductions of about $5^{\circ} \mathrm{C}$ in the area-weighted surface temperature $\left(\mathrm{T}_{\mathrm{a}}\right)$ and $0.15^{\circ} \mathrm{C}$ in its associated standard deviation $\left(\sigma_{\mathrm{a}}\right)$ are achieved as the microchannel width is decreased from 0.5 to $0.2 \mathrm{~mm}$. Accordingly, enhancements of about $0.75 \mathrm{~W}$ for the generated power $\left(\mathrm{P}_{\mathrm{g}}\right)$ and $0.61 \mathrm{~W}$ for net output power $\left(\mathrm{P}_{\text {net }}\right)$ are attained. The difference between the augmentations in both powers is due to the increase in the pumping power $\left(\mathrm{P}_{\mathrm{p}}\right)$ as the microchannel width decreases. As the microchannel width is decreased the microchannel thermal resistance $\left(R_{m}\right)$ and total thermal resistance $\left(R_{t}\right)$ decrease whereas the overall heat transfer coefficient $(\mathrm{U})$ and the pressure drop $(\square \mathrm{p})$ increase.

\subsection{Effect of microchannel depth}

The depth of microchannels is studied for $0.2,0.3,0.4$ and $0.5 \mathrm{~mm}$. Fig. $4 \mathrm{~d}$ shows that the average HCMJPV surface temperature increases from about 65 to $67^{\circ} \mathrm{C}$ and the fluctuations in the temperature distributions increase as the microchannel depth is increased from 0.2 to $0.5 \mathrm{~mm}$. However, the effects of microchannel depth on the HCMJPV output power and the thermal characteristics of the HCMJPV cooling system are presented in Table 1d. The large increase in the pressure drop and pumping power overwhelms the enhancement of generated power as the microchannel depth is decreased. This is due to the increase in water velocity which 
causes the pressure drop and consequently the pumping power to increase. Therefore, the HCMJPV module that uses a cooling system with the smallest microchannel depth of $0.2 \mathrm{~mm}$ produces the largest generated power and the lowest net output power among the considered microchannel depth. Based on the data in Table $1 \mathrm{~d}$, a microchannel depth of 0.3 and $0.4 \mathrm{~mm}$ produce compromise results of net output power and temperature uniformity.

\subsection{Effect of TIM properties}

Careful examination of the tabulated results revealed that the total thermal resistance is about 3 times the thermal resistance of microchannels. The main cause of that is the low thermal conductivity of the TIM material that seems to partially insulate the cell base from the microchannels in the cooling system. The available TIMs have various thermophysical properties than the one tested before by Riera et al. [9] and others. Table 2 lists the thermophysical properties of three considered materials with significant variations in their properties. Therefore, the effect of TIMs is studied for the two available commercial materials, namely GAP FILLER 4000, THERAM-A-GAP GELL (GELL 8010) in addition to the classical metal oxide filled silicone oil paste that was tested before. Each of the three materials was examined under the same design and boundary conditions. Although the TIM response is due to its thermal conductivity, specific heat and mass density, the TIMs will be ranked according to their thermal conductivity as it is the most influential property. The simulation results are presented in Fig. 4e and Table 1e where outstanding improvements in the system characteristics are noted.

Table 2. Thermophysical properties of TIMs

\begin{tabular}{|l|c|c|c|}
\hline Property & $\begin{array}{c}\text { METAL OXIDE } \\
\text { FILLED SILICONE OIL } \\
\text { PASTE }\end{array}$ & $\begin{array}{c}\text { THERAM-A-GAP } \\
\text { GELL (GELL 8010) }\end{array}$ & $\begin{array}{c}\text { GAP FILLER } \\
\mathbf{4 0 0 0}\end{array}$ \\
\hline density, $\mathrm{kg} / \mathrm{m}^{3}$ & 2000 & 2700 & 3100 \\
\hline specific heat, $\mathrm{J} / \mathrm{kgK}$ & 712 & 1000 & 800 \\
\hline thermal conductivity, $\mathrm{W} / \mathrm{mK}$ & 0.82 & 3 & 4 \\
\hline
\end{tabular}

Table 1e indicates that the cell surface temperature decreases by over $24^{\circ} \mathrm{C}$, the overall heat transfer coefficient is doubled and the total thermal resistance decreases to less than half its previous value with $\mathrm{k}=0.82 \mathrm{~W} / \mathrm{mK}$. As the surface temperature decreases by about $24^{\circ} \mathrm{C}$, the generated and net output power increase by about $5.5 \%(3.74 \mathrm{~W})$. On the other hand, the standard deviation is increased by about 0.26 and $0.31 \square \mathrm{C}$ for TIM with thermal conductivities of 3 and $4 \mathrm{~W} / \mathrm{mK}$. Changes in the microchannel thermal resistance and the pumping power for various TIMs are negligible. The increase in standard deviation as the thermal conductivity increases is in agreement with the finding reported by Riera et al. [40]. Thus, the use of the advanced TIM with $\mathrm{k}=4 \mathrm{~W} / \mathrm{mK}$ enhances the performance and characteristics of the cooling system over those with TIM of $\mathrm{k}=0.82 \mathrm{~W} / \mathrm{mK}$ substantially. 


\subsection{Comparison with Riera's Design}

The critical review in section 1 revealed that the most advanced and efficient cooling system for HCMJPV is developed and reported by Riera et al. [9]. Therefore, a comprehensive comparison between the characteristics of the cooling systems developed during the present work and that in [9] is conducted in this section. In order to evaluate the geometrical design and the concept of short water path of the present work, the comparison is performed while the present cooling system uses either TIM with $\mathrm{k}=0.82 \mathrm{~W} / \mathrm{mK}$ or $4 \mathrm{~W} / \mathrm{mK}$. The comparison with $\mathrm{k}=4 \mathrm{~W} / \mathrm{mK}$ is performed to assess the final achievements of the present work. Table 3 lists the numerical values of the comparison where "+" sign means higher than and "-" sign lower than Riera' cooling system.

Table 3 presents the characteristics of Riera's design along with those of the present cooling system that yields the maximum net output power using TIM with thermal conductivity of $0.82 \mathrm{~W} / \mathrm{mK}$. Comparing the results of the present cooling system with those of the five stepwise microchannels [9] indicated that the surface temperature and its standard deviation along with the thermal resistances of the first are lower than the second by 11.3 and $0.41^{\circ} \mathrm{C}$, respectively. Also, the generated and the net output power and the overall heat transfer coefficient of the present cooling system are better than those in [9]. Specifically, the generated power is better by $2.63 \%$, the net output power by $2.79 \%$, the overall heat transfer coefficient is better by about $25.0 \%$ and the thermal resistance of microchannels is better by $49.4 \%$.

The comparison between Riera's design and the present cooling systems, with TIM of $\mathrm{k}=4 \mathrm{~W} / \mathrm{mK}$ revealed the significant and outstanding effect of the present cooling system. The comparable standard deviation of temperature is achieved with $35.5^{\circ} \mathrm{C}$ lower surface temperature and $175.8 \%$ higher overall heat transfer coefficient. About 5.62W (8.44\%) larger net output power than Riera's design is achieved for the present cooling system. This excess power yields about $820.5 \mathrm{MWh}$ per square meter of cells, based on 10 working hours daily during 25 years lifetime of cells.

Table 3. Comparison between Riera's design and cooling systems for maximum net output power with TIM thermal conductivity of $0.82 \mathrm{~W} / \mathrm{mK}$

\begin{tabular}{|c|c|c|c|c|c|c|c|c|c|c|}
\hline Conditions & $\begin{array}{l}\text { Width } \\
\text { mm }\end{array}$ & $\begin{array}{c}\mathrm{T}_{\mathrm{mw}} \\
{ }^{\circ} \mathrm{C}\end{array}$ & $\begin{array}{c}\sigma_{\mathrm{mw}} \\
{ }^{\circ} \mathrm{C}\end{array}$ & $\begin{array}{l}\mathrm{R}_{\mathrm{t}} \times 10^{-5} \\
\mathrm{~m}^{2} \mathrm{~K} / \mathrm{W}\end{array}$ & $\begin{array}{l}\mathrm{R}_{\mathrm{m}} \times 10^{-5} \\
\mathrm{~m}^{2} \mathrm{~K} / \mathrm{W}\end{array}$ & $\begin{array}{c}\mathrm{U} \\
\mathrm{kW} / \mathrm{m}^{2} \mathrm{~K}\end{array}$ & $\begin{array}{l}\Delta \mathrm{p} \\
\mathrm{kPa}\end{array}$ & $\begin{array}{l}\mathrm{P}_{\mathrm{p}} \\
\mathrm{W}\end{array}$ & $\begin{array}{l}P_{g} \\
W\end{array}$ & $\begin{array}{c}P_{\text {net }} \\
W\end{array}$ \\
\hline iera' & -0.14 & 77.50 & 0.900 & 11.10 & 4.680 & 9.009 & 28.97 & 0.2549 & 66.89 & 66.63 \\
\hline & & 66.23 & & & & 11.26 & 9.174 & 0.1615 & 68.65 & 68.49 \\
\hline & & 42.00 & 99 & 4.02 & 2.36 & 24.85 & 9.151 & 0.1610 & 72.42 & 72.25 \\
\hline \multicolumn{2}{|c|}{$\begin{array}{l}\text { Comparison with present work } \\
\text { at } \mathrm{k}=0.82 \mathrm{~W} / \mathrm{mK}\end{array}$} & $11.3^{\circ} \mathrm{C}$ & $0.41^{\circ} \mathrm{C}$ & $20.0 \%$ & $49.4 \%$ & $\stackrel{+}{+}$ & $68.3 \%$ & $36.6 \%$ & $\stackrel{+}{2.63 \%}$ & $\begin{array}{c}+ \\
2.79 \%\end{array}$ \\
\hline \multicolumn{2}{|c|}{$\begin{array}{l}\text { Comparison with present work } \\
\text { at } \mathrm{k}=4 \mathrm{~W} / \mathrm{mK}\end{array}$} & $5.50^{\circ} \mathrm{C}$ & $\stackrel{+}{0.01^{\circ} \mathrm{C}}$ & $63.78 \%$ & $\begin{array}{c}- \\
49.57 \%\end{array}$ & $\begin{array}{c}+ \\
175.8 \%\end{array}$ & $68.41 \%$ & $-\overline{-}$ & $\stackrel{+}{8.27 \%}$ & $\stackrel{+}{8.44 \%}$ \\
\hline
\end{tabular}




\subsection{Concluding discussion}

The effects of the investigated design parameters on the thermal characteristics of the cooling system and the net output power of HCMJPV cells indicated the substantial effect of the thermal conductivity of TIM, followed by the width and depth of the microchannels. On the other hand, the temperature uniformity of the HCMJPV surface is most affected by the inlet jet width followed by the TIM and microchannel width and depth. The effect of outlet slot width is not important on either the output power or temperature uniformity.

The cost of PV cooling consists of the initial, running, and maintenance costs of the system. The reported work in literature focuses only on the pumping power [12, 42] as it represents the major cost of the system. The pumping power of the present system is lower than Riera's system by $36.8 \%$ (Table 3 ). Therefore, the cost of the pumping power will be less than $2 / 3$ of the state of the art system. In addition, the present system consists of four sections of constant-width microchannels whereas the state of the art system contains two stages each of five stepwise microchannels (10 sections of various microchannels width). Thus, the present system is simpler than the state of the art system and the cost of production and maintenance is definitely lower than the other system.

In conclusion, the proposed cooling system that is based on the idea of shortening the length of the cooling water path is the simplest design compared to the five stepwise microchannels. Thus, the production, operation, and maintenance costs of this system will be considerably lower than any stepwise system. Moreover, this simpler system achieves the best thermal and electrical characteristics among the considered systems as revealed in Table 3. It achieves the highest net output power and overall heat transfer coefficient with the lowest thermal resistance.

\section{Conclusion}

The simple, effective and economic microchannel cooling system for highconcentration multi-junction photovoltaic (HCMJPV) cells are developed during the course of this work. While the state of the art cooling system used five stepwise microchannels per fluid path, the developed cooling systems is using one microchannel section with a short fluid path. The results confirm that the short fluid path enhances the thermal characteristics of the cooling system that allow the HCMJPV cells to generate larger power and produce larger net output power. The design of the new system was based on a comprehensive investigation of the effects of various design parameters on the characteristics of the cooling system. Based on the reported results, the following conclusions may be drawn:

- The developed constant-width one-section microchannel cooling system using thermal interface material (TIM) with thermal conductivity of $4 \mathrm{~W} / \mathrm{mK}$ attains comparable standard deviation and lower surface temperature $\left(35.5^{\circ} \mathrm{C}\right)$, pressure drop $(68.41 \%)$ and microchannel thermal resistance $(49.57 \%)$ along with higher generated power $(8.27 \%)$, net output power 
$(8.44 \%)$ and overall heat transfer coefficient $(175.8 \%)$ compared to the five stepwise microchannels cooling system reported in literature.

- The increase in net output power produced by HCMJPV cells using the present cooling system over those in literature offers excess energy of about 820.5MWh, per square meter of cells, during their 25 years lifetime.

- The thermal interface material has a substantial effect on the effectiveness of the cooling system and the power produced by the HCMJPV cells. As the thermal conductivity of TIM is increased from 0.82 to $4 \mathrm{~W} / \mathrm{mK}$, the surface temperature drops by more than $24^{\circ} \mathrm{C}$ and the net power increases by about $4 \mathrm{~W}$. Also, the overall heat transfer coefficient is more than doubled.

- The net output power and the surface temperature of the HCMJPV cells are significantly affected by the thermal conductivity of TIM, followed by the depth and width of the microchannels whereas the effects of inlet jet width and microchannel length are moderate and the effect of outlet slot width is not important.

- Temperature uniformity of the HCMJPV surface is most affected by the microchannel width followed by the inlet jet width and the microchannel depth.

\section{Nomenclature}

\begin{tabular}{|c|c|c|}
\hline Symbol & Description & Units \\
\hline A & Area & $\mathrm{m}^{2}$ \\
\hline$c_{\mathrm{p}}$ & Specific heat & $\mathrm{J} / \mathrm{kgK}$ \\
\hline $\mathrm{k}$ & Thermal conductivity & $\mathrm{W} / \mathrm{mK}$ \\
\hline $\mathrm{L}$ & Layer thickness & $\mathrm{m}$ \\
\hline $\mathrm{p}$ & Pressure & $\mathrm{Pa}$ \\
\hline$P$ & Power & $\mathrm{W}$ \\
\hline $\mathrm{P}_{\mathrm{w}}$ & Wetted perimeter & $\mathrm{m}$ \\
\hline$q^{\prime \prime}$ & Heat flux & $\mathrm{W} / \mathrm{m}^{2}$ \\
\hline $\mathrm{q}_{\mathrm{g}}$ & Generated electrical power per unit area of HCPV cell & $\mathrm{W} / \mathrm{m}^{2}$ \\
\hline Q & Volume flow rate of water & $\mathrm{m}^{3} / \mathrm{s}$ \\
\hline $\mathrm{R}$ & Thermal resistance & $\mathrm{m}^{2} \mathrm{~K} / \mathrm{W}$ \\
\hline $\mathrm{T}$ & Temperature & ${ }^{\circ} \mathrm{C}$ \\
\hline $\mathrm{U}$ & Overall heat transfer coefficient & $\mathrm{W} / \mathrm{m}^{2} \mathrm{~K}$ \\
\hline V & Inlet water velocity & $\mathrm{m} / \mathrm{s}$ \\
\hline \multicolumn{3}{|c|}{ Greek symbols } \\
\hline $\begin{array}{l}\alpha \\
\Delta\end{array}$ & $\begin{array}{l}\text { Relative temperature coefficient of HCMJPV cell }=0.0531 \\
\text { difference }\end{array}$ & $\% /{ }^{\circ} \mathrm{C}$ \\
\hline$\eta_{c}\left(T_{a}\right)$ & Temperature dependence convergent coefficient of HCMJPV cell & \\
\hline$\rho$ & Density & $\mathrm{kg} / \mathrm{m}^{3}$ \\
\hline$\sigma$ & $\begin{array}{c}\text { The standard deviation of HCMJPV surface temperature } \\
\text { Subscripts }\end{array}$ & ${ }^{\circ} \mathrm{C}$ \\
\hline a & area-weighted average of HCMJPV surface & \\
\hline av & average & - \\
\hline g & generated & \\
\hline in & inlet & \\
\hline $\mathrm{m}$ & microchannel & - \\
\hline
\end{tabular}




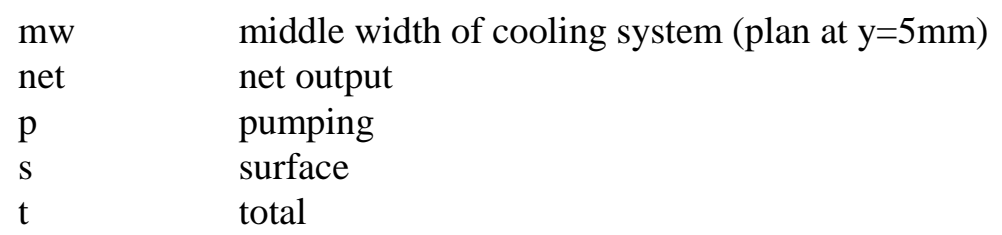

\begin{tabular}{|c|c|}
\hline & Abbreviations \\
\hline CFD & Computational Fluid Dynamics \\
\hline CMJPV & Concentrated Multi-Junction Photovoltaic \\
\hline CPV & Concentrated Photovoltaic \\
\hline $\mathrm{CR}$ & Concentration Ratio \\
\hline DNI & Direct Normal Irradiance \\
\hline HCMJPV & High-Concentration Multi-Junction Photovoltaic \\
\hline $\mathrm{HCPV}$ & High Concentrated Photovoltaic \\
\hline IC & Integrated Circuits \\
\hline MJPV & Multi-Junction Photovoltaic \\
\hline PV & Photovoltaic \\
\hline UDF & User Defined Function \\
\hline TIM & Thermal Interface Material \\
\hline
\end{tabular}

\section{References:}

[1] IRENA-The International Renewable Energy Agency, Renewable energy statistics 2019, 2019, Abu Dhabi.

[2] G. K. Singh, Solar power generation by PV (photovoltaic) technology: A review, Energy 53 (2013) 1-13.

[3] B. Parida, S. Iniyan, and R. Goic, A review of solar photovoltaic technologies, Renewable and Sustainable Energy Reviews 15 (3) (2011) 1625-1636.

[4] E. Radziemska, The effect of temperature on the power drop in crystalline silicon solar cells, Renewable Energy 28 (2003) 1-12.

[5] S. Jakhar, M. S. Soni, and N. Gakkhar, Historical and recent development of concentrating photovoltaic cooling technologies, Renewable and Sustainable Energy Reviews 60 (2016) 41-59.

[6] D. lee, and S. W. Beal, Development of a heating system using CPV technology and heat pipes, Environmental Progress and Sustainable Energy 33 (2) (2015) 482-489.

[7] S. Nižetić, A. M. Papadopoulos, and E. Giama, Comprehensive analysis and general economic-environmental evaluation of cooling techniques for photovoltaic panels, Part I: Passive cooling techniques, Energy Conversion and Management 149 (2017) 334-354.

[8] S. Nižetić, E. Giama, and A. M. Papadopoulos, Comprehensive analysis and general economic-environmental evaluation of cooling techniques for photovoltaic panels, Part II: Active cooling techniques, Energy Conversion and Management 155 (2018) 301-323.

[9] S. Riera, J. Barrau, M. Omri, L. G. Fréchette, and J. I. Rosell, Stepwise varying width microchannel cooling device for uniform wall temperature: Experimental and numerical study, Applied Thermal Engineering 78 (2015) 30-38.

[10] D. Montorfano, A. Gaetano, M. C. Barbato, G. Ambrosetti, and A. Pedretti, CPV cells cooling system based on submerged jet impingement: CFD modeling and experimental validation, in: AIP Conference Proceedings 1616 (2014): 135-139.

[11] A. Royne, C. J. Dey, and D. R. Mills, Cooling of photovoltaic cells under concentrated illumination: A critical review, Solar Energy Materials and Solar Cells 86 (4) (2005) 451-483. 
[12] N. Gilmore, V. Timchenko, and C. Menictas, Microchannel cooling of concentrator photovoltaics: A review, Renewable and Sustainable Energy Reviews 90 (2018) 1041-1059.

[13] D. B. Tuckerman and R. F. W. Pease, High-performance heat sinking for VLSI, IEEE Electronic Device Letters 2 (5) (1981) 126-129.

[14] Y.-J. Lee, P. Lee, and S. Chou, Enhanced microchannel heat sinks using oblique fins, ASME 2009 InterPACK Conference, San Francisco, California, USA, July 19-23, 2009 Vol. 2 (2009): 253-260.

[15] L. Micheli, S. Senthilarasu, K. S. Reddy, and T. K. Mallick, Applicability of silicon micro-finned heat sinks for 500x concentrating photovoltaics systems, Journal of Materials Science 50 (16) (2015) 5378-5388.

[16] K. S. Reddy, S. Lokeswaran, P. Agarwal, and T. K. Mallick, Numerical investigation of micro-channel based active module cooling for solar CPV system, Energy Procedia 54 (2014) 400-416.

[17] A. A. Alfaryjat, H. A. Mohammed, N. M. Adam, M. K. A. Ariffin, and M. I. Najafabadi, Influence of geometrical parameters of hexagonal, circular, and rhombus microchannel heat sinks on the thermohydraulic characteristics, International Communication in Heat and Mass Transfer 52 (2014) 121-131.

[18] N. Tran, Y. Chang, J. Teng, and R. Greif, A study on five different channel shapes using a novel scheme for meshing and a structure of a multi-nozzle microchannel heat sink, International Journal of Heat and Mass Transfer 105 (2017) 429-442.

[19] B. Ramos-Alvarado, P. Li, H. Liu, and A. Hernandez-Guerrero, CFD study of liquidcooled heat sinks with microchannel flow field configurations for electronics, fuel cells, and concentrated solar cells, Applied Thermal Engineering 31 (14-15) (2011) 2494-2507.

[20] J. Dong, X. Zhuang, X. Xu, Z. Miao, and B. Xu, Numerical analysis of a multichannel active cooling system for densely packed concentrating photovoltaic cells, Energy Conversion and Management 161 (2018) 172-181.

[21] W. Escher, T. Brunschwiler, B. Michel, and D. Poulikakos, Experimental investigation of an ultrathin manifold microchannel heat sink for liquid-cooled chips, Journal of Heat Transfer 132 (8) (2010) 081402, doi:10.1115/1.4001306.

[22] K. Yang, and C. Zuo, A novel multi-layer manifold microchannel cooling system for concentrating photovoltaic cells, Energy Conversion and Management 89 (2015) 214221.

[23] Y. Yue, S. K. Mohammadian, and Y. Zhang, Analysis of performances of a manifold microchannel heat sink with nanofluids, International Journal of Thermal Sciences 89 (2015) 305-313.

[24] M.S.Y. Ebaid, A.M. Ghrair, and M. Al-Busoul, Experimental investigation of cooling photovoltaic $(\mathrm{PV})$ panels using $\left(\mathrm{TiO}_{2}\right)$ nanofluid in water-polyethylene glycol mixture and $\left(\mathrm{Al}_{2} \mathrm{O}_{3}\right)$ nanofluid in water cetyltrimethylammonium bromide mixture, Energy Conversion and Management 155 (2018) 324-343.

[25] Y. Sui, C. J. Teo, P. S. Lee, Y. T. Chew, and C. Shu, Fluid flow and heat transfer in wavy microchannels, International Journal of Heat and Mass Transfer 53 (13-14) (2010) 2760-2772.

[26] Y. Sui, C. J. Teo, and P. S. Lee, Direct numerical simulation of fluid flow and heat transfer in periodic wavy channels with rectangular cross-sections, International Journal of Heat and Mass Transfer 55 (1-3) (2012) 73-88.

[27] J. Zhang, P. T. Lin, and Y. Jaluria, Design and optimization of multiple microchannel heat transfer systems, Journal of Thermal Science and Engineering Applications 6 (1) (2013) 011004, doi: 10.1115/1.4024706.

[28] G. Wang, D. Niu, F. Xie, Y. Wang, X. Zhao, and G. Ding, Experimental and 
numerical investigation of a microchannel heat sink (MCHS) with micro-scale ribs and grooves for chip cooling, Applied Thermal Engineering 85 (2015) 61-70.

[29] R. Leena, G. Syamkumar, and M. Jose Prakash, Experimental and numerical analyses of multiple jets impingement cooling for high-power electronics, IEEE Transactions Components, Packaging and Manufacturing Technology 8 (2) (2018) 210-215.

[30] P. Naphon, L. Nakharintr, and S. Wiriyasart, Continuous nanofluids jet impingement heat transfer and flow in a micro-channel heat sink, International Journal of Heat and Mass Transfer 126 (2018) 924-932.

[31] E. M. Dede, Optimization and design of a multipass branching microchannel heat sink for electronics cooling, Journal of Electronic Packaging 134 (4) (2012) 041001.

[32] O. Lamini and C. Y. Zhao, Study on moving nozzle effects on spray cooling of electronics, 2018 International Conference on Electronics Packaging and iMAPS All Asia Conference (ICEP-IAAC 2018) 443-447.

[33] Y. Han, B. L. Lau, G. Tang, X. Zhang, and D. M. W. Rhee, Si-based hybrid microcooler with multiple drainage microtrenches for high heat flux cooling, IEEE Transactions Components, Packaging and Manufacturing Technology 7 (1) (2017) $50-57$.

[34] T. Ming, C. Cai, W. Yang, W. Shen, W. Feng, and N. Zhou, Optimization of dimples in microchannel heat sink with impinging jets-part A: the influences of dimple height and arrangement, Journal of Thermal Science 27 (4) (2018) 321-330.

[35] J. Barrau, M. Omri, D. Chemisana, J. Rosell, M. Ibañez, and L. Tadrist, An experimental study of a new hybrid jet impingement/micro-channel cooling scheme, Applied Thermal Engineering 33-34 (1) (2010) 237-245.

[36] J. Barrau, J. Rosell, D. Chemisana, L. Tadrist, and M. Ibañez, Effect of a hybrid jet impingement/micro-channel cooling device on the performance of densely packed PV cells under high concentration, Solar Energy 85 (11) (2011) 2655-2665.

[37] J. H. Ryu, D. H. Choi, and S. J. Kim, Numerical optimization of the thermal performance of a microchannel heat sink, International Journal of Heat and Mass Transfer 45 (2002) 2823-2827.

[38] J. Barrau, A. Perona, A. Dollet, and J. Rosell, Outdoor test of a hybrid jet impingement/micro-channel cooling device for densely packed concentrated photovoltaic cells, Solar Energy 107 (2014) 113-121.

[39] S. Riera, J. Barrau, J. I. Rosell, M. Omri, and L. G. Fréchette, Experimental demonstration of a tailored-width microchannel heat exchanger configuration for uniform wall temperature, Journal of Physics Conference series 476 (1) (2013): 0-5.

[40] S. Riera, J. Barrau, J. I. Rosell, L. Fréchette, M. Omri, M. Vilarrubí, and G. Laguna, Smoothing effect of the thermal interface material on the temperature distribution in a stepwise varying width microchannel cooling device, Heat and Mass Transfer/Waerme und Stoffuebertragung 53 (9) (2017) 2987-2997.

[41] M. Vilarrubí, S. Riera, M. Ibañez, M. Omri, G. Laguna, L. G. Fréchette, and J. Barrau, Experimental and numerical study of micro-pin-fin heat sinks with variable density for increased temperature uniformity, International Journal of Thermal Sciences 132 (June) (2018) 424-434.

[42] R. Nadda, A. Kumar, and R. Maithani, Efficency improvement of solar photovoltaic/solar air collectors by using impingement jets: A review, Renewable and Sustainable Energy Reviews 93 (2018) 331-353. 